\title{
NATURAL RESOURCE MANAGEMENT AND RESOURCE RIGHTS FOR AGRICULTURE
}

\section{Frank Place, Ruth Meinzen-Dick, and Hosaena Ghebru}

For the foreseeable future, agriculture in developing countries will be overwhelmingly based on farming that is dependent on natural resources to produce edible plants, provide feed for livestock, or to raise fish. The abundance of natural resources affects total agricultural production but the health, state, or quality of natural resources affects both total production and productivity of agriculture. Productivity growth in agriculture is of paramount importance for feeding growing populations in a world with limited natural resources (FAO 2012b). However, achieving high productivity is not easily accomplished in smallholder-dominant countries as evidenced by high yield gaps-the difference between actual and potential yields-in much of the developing world (FAO 2011) and productivity gaps between agriculture and other sectors (Gollin, Lagakos, and Waugh 2014). Obtaining high productivity in a way that sustainably uses natural resources is even more elusive globally.

The concept of environmental sustainability has two important dimensions. The first is whether the productivity of the current land under agriculture can be maintained or increased over time through the prevention of soil degradation, overuse of water, and other destructive practices (for example, salinization). The second is whether this productivity can be maintained without creating adverse effects on offsite natural resources. Negative externalities are manifested in flows of soil, nutrients, and wastes associated with agriculture that move on surfaces or below surfaces or atmospheric borne effects such as with greenhouse gases or silt. They are also manifested by expansion of agriculture into new land areas, which is destructive to forests, wetlands, and other natural habitats, and by negative changes in biodiversity (loss of wild species, agrobiodiversity, or increase of pests). It is apparent that farming involves or touches many types of natural resources that are both near and far from farms. This of course involves many stakeholders and poses great challenges for natural resource governance and property rights systems. 
This chapter begins with a discussion of the importance of natural resources for agriculture and the links between agriculture and surrounding natural resources. It presents evidence on trends in natural resources use in agriculture and the drivers behind those changes. Also described are the many technological and institutional natural resource management (NRM) options that have proven to be successful, at least in some settings, as well as the main factors that restrain their wider use. The chapter focuses on tenure and governance challenges in managing natural resources for the benefit of users and wider society. Some recent innovations in tenure and governance of natural resources are discussed as well as an exploration of how well they perform in terms of achieving efficiency, equity, and sustainability objectives. The chapter concludes with key messages as well as a summary of the major development challenges and knowledge gaps.

\section{Natural Resources and Agriculture}

Soil and water are essential natural resources for agriculture. Soils have physical, chemical, and biological attributes-all of which contribute to soil health and subsequent productivity of agriculture (Sanchez 2019). Although all three properties can be degraded quickly through erosion, they have different timescales for their enrichment. Soil chemical properties can be changed most quickly through additions of nutrients, while some soil physical properties take decades to rebuild. Soils themselves have complex relationships with other natural resources; soils determine the degree to which other vegetation, such as trees and grasses, thrive while the integration of certain types of plants or their derivatives can enrich soils. Soil processes occur at a small scale (for example, in situ effects of no tillage) and at a large scale (for instance, soils are key to global carbon and nitrogen cycles and some of the other planetary boundaries) (Rockström et al. 2009).

Water for agriculture is largely from rainfall, but techniques exist to collect and move water both within farms (for example, water harvesting ponds or drip irrigation) and across larger land areas (for instance, canal irrigation schemes or pumping from aquifers) (Comprehensive Assessment of Water Management in Agriculture 2007). Managing water for agriculture is particularly important when rainfall is erratic and can in some cases extend the growing season or number of growing seasons within a calendar year. In addition, water flows across (and under) landscapes are affected by land use including farm management practices. Water for agriculture is therefore immediately 
recognizable as a landscape or catchment-level issue, and its management almost always involves externalities.

Important natural resources for farming go beyond soil and water. On farms the strategic use of agrobiodiversity, including edible or nonedible plants, can improve soil and water conservation, reduce exposure to pests and disease, or reduce wind damage to crops. They also serve as feed for livestock and beekeeping. Trees can provide for microclimate benefits through effects on ground temperatures and improving soil structures (Lasco et al. 2014). Leguminous plants can provide organic nutrients to nourish crops in the short term and to improve soil biology in the medium to long term (Peoples et al. 2009). These same plants can be important when found on nonagricultural lands to stem soil erosion, improve water infiltration and groundwater replenishment, provide needed feed for livestock, and host pollinator species. Livestock can be viewed as a natural resource that provides an important function of converting biomass into a high-quality manure. Forests and woodlands are sources of food (for example, wild fruits) and help to regulate water services in agriculture areas.

As described, the management of natural resources on farms not only has obvious direct effects on the farms. In addition, there are possible significant externalities from the management of natural resources and other farm practices within agriculture. Important negative externalities include sediment flow into rivers, chemical leaching into water supplies, deforestation, overgrazing, reduction in biodiversity, and greenhouse gas emissions. However, some types of practices may have positive externalities such as carbon sequestration, soil erosion control, and evapotranspiration effects (Kremen and Miles 2012). Reducing agriculture's negative environmental effects and enhancing its positive externalities is much discussed in global policy fora (for example, Food and Land Use Coalition 2019). The direction and level of externalities are highly influenced by the security of rights and management systems of local users over natural resources.

\section{Trends of Natural Resources in Agriculture}

The area under agriculture in developing countries has been increasing rapidly, by 230 million hectares between the early 1960s and mid-2000s (FAO 2012b). The trend in agricultural land area up to the mid-2010s varies by region and country, slightly declining in such places as China and India (where peaks were around 1990), slowing in such densely populated countries as Kenya 
and Rwanda, but still expanding in others with lower rural population densities (for example, the Democratic Republic of the Congo, Mozambique, and Zambia). It is expected that a further increase of 107 million hectares will be needed by 2050 to feed the increased population of the current developing countries (FAO 2012b).

Recent studies demonstrate that there has been significant degradation of land and soil quality. Le, Nkonya, and Mirzabaev (2016) find that globally 25 percent of cultivated land is degrading (as measured by declining plant productivity) over the past 25 years as has more than 30 percent of land used for livestock grazing. One key factor behind these trends is the continuous use of land with little fallowing and insufficient use of biological or mineral inputs, resulting in nutrient mining (Henao and Banaante 2006). Another is poor conservation of soils, resulting in soil erosion of the more productive top layers (Tamene and Le 2015).

Most of agriculture is based on rainfed conditions with irrigation used on only 16 percent to 20 percent of arable land (FAO 2011). China and India account for more than half of the irrigated area (54 percent) in developing countries (FAO 2011). In Africa south of the Sahara, only 3 percent of cultivated land is irrigated (Calzadilla 2013). There had been significant expansion of irrigation in developing countries in the latter half of the 1900s, but the pace has slowed since 2000. Some water resources are becoming depleted-for example, groundwater in West Asia, North Africa, and India, and glacier reservoirs in the Himalayas and Andes-and climate change may reduce rains in other areas (for example, southern Africa). Furthermore, continued population growth increases demand for domestic water use and competes with water supplies for agriculture. Water quality is also poor and threatened in many cases. It was estimated that 21 percent of surface water in China was unfit even for agriculture (2030 Water Resources Group 2009).

Forest, tree, and other vegetative cover is important for conserving soils on landscapes and for regulating watershed hydrology, and has been identified as terrestrial sources of rainfall through evapotranspiration (Ellison et al. 2017). Deforestation continues (about 130 million hectares of forests between 2000 and 2010), is slowing, or is reversing in many important countries such as China and India (FAO 2012a) but increased overall in the tropics in 2017 (Weisse and Goldman 2018). The effects of global deforestation on loss of carbon sequestration is partly offset by increasing tree cover on agricultural land (Zomer et al. 2016). 


\section{Drivers of Availability and Degradation of Natural Resources}

Among the anthropogenic factors affecting trends in natural resource availability and quality are urban and rural population growth, development of markets for agriculture and other natural resource-based products, and policies that affect the ways in which people use resources. Population growth, whether urban or rural, raises the demand for food, historically resulting in the expansion of agricultural land. This has negative consequences on such natural habitats as forests, shrublands, and wetlands, which are converted to agriculture. Conversion to agriculture is the proximate cause of about 80 percent of deforestation (Kissinger, Herold, and De Sy 2012). The other effect of increasing rural population density is to reduce the median farm size, most noticeably in Africa (AGRA 2013). This can lead to either better or worse natural resource management on farms, depending on such factors as market conditions and property rights systems.

Market development will affect incentives to manage natural resources on farms or in landscapes. These could be positive-for example, by increasing the returns to on-farm investments in soil fertility management, water management, and other similar practices through better access to productivityenhancing inputs as well as increasing the ratio of output to input prices. These could be negative as well, creating incentives to overextract or mine resources to seize market opportunities. The direction of this effect depends on clarity and security of resource rights, especially long-term rights. Market development also includes markets for the resources or the ecosystem services they may provide (Kroeger and Casey 2007). Land markets are subjected to a variety of legal and nonlegal barriers, markets for water are rarely formalized in rural areas, and the valuation and recognition of environmental services is only operational in a few pilot cases. Markets for watershed protection services, carbon sequestration, or other ecosystem services have emerged and are growing but are still uncommon and minor contributors to income streams of rural resource users (Salzman et al. 2018). Finally, property rights and governance institutions play a key role in shaping the ways in which natural resources are exploited, managed, and conserved, which is the main topic discussed in this chapter.

\section{Natural Resource Management Practices and Institutional Approaches in Agriculture}

This section does not attempt to provide a comprehensive review of natural resource practices used by farmers and communities or to explore all the links 
between the management of natural resources and agriculture. The purpose is rather to introduce a range of practices and to identify important constraints farmers or communities face in adopting them to better understand the role of tenure factors in NRM.

Farmers in developing countries use a variety of natural resource management practices on their farms. The specific practices that are applied vary considerably depending on the local context (for example, soil type, aridity, level of market development for inputs and outputs) and household characteristics (for instance, farm size, available family labor for agriculture) (see, for example, Vanlauwe et al. 2015). Most soils in the tropics have deficiencies in physical structure (for instance, high sand content), chemical composition (high acidity or low phosphorus), or poor biological activity (low soil carbon and microbial function) (Sanchez 2019). In these cases the conventional approach of relying only on mineral fertilizer to generate consistently high yields will not work (Marenya and Barrett 2009), and other soil management strategies are necessary.

Some dimensions of soil health can be affected by NRM practices in the short- to medium-term and thus be attractive for farmers to invest in. This includes the planting of trees and shrubs to help break hard pans and improve water retention, the use of minimum tillage to improve soil biological function, and the application of mulch or conservation structures to reduce top soil degradation. Soil conservation practices are varied and include terracing and ridging, which themselves can be formed through altering the soil through labor, applying materials like stones, or planting grass strips or other plants. Soil biology is improved mainly through application of organic matter and farmers use a variety of methods to achieve this, including use of animal manure or compost, incorporation of crop residues, natural or planted fallowing, and application of green mulch from woody or herbaceous plants often grown in situ. Acidic soils require an offsetting chemical agent like lime to be applied. These practices are also referred to as sustainable land management practices (SLM).

Water is another essential natural resource for agriculture and its effective management can lead to significant effects on production. There are some practices that simply encourage rain to accumulate in areas where farmers intend to plant seed. These include planting basins, zai pits, half-moons, or any other type of excavated area where water can accumulate and infiltrate. Soil conservation structures will also act to manage water and prevent it from moving too fast or far on the surface. Runoff may be stored in an on-farm source such as a water pan, farm pond, or container. Rooftop water harvesting 
may be used for domestic water supply and homestead gardens. Farmers construct channels that can be used to move water onto or off of fields. Water can also be moved via hoses above or below ground (for example, drip irrigation).

Beyond such on-farm water control, watershed management is one of the clearest examples of landscape-level NRM. This may involve technical interventions such as building check dams to slow water flows or increase recharge, terracing, planting trees, or buffer strips along waterways to protect against pollution, but generally also include some forms of restrictions on behavior, such as excluding animals from grazing in certain areas or limiting water withdrawals. Kerr (2007: 91) notes that "technical interventions are likely to be fruitless without subsequent management." This management depends on institutional arrangements—-rules that are set, adapted, and enforced.

Most irrigation draws water from an off-farm source of water such as a reservoir, canal, river, pond, or aquifer. These require investment and coordination above the level of the individual farm to construct, operate, and maintain the system as well as to regulate the timing and amounts of water flows and withdrawals across users. The importance of these institutional factors for irrigation use has often been noted, as in the experimental study in Burney and Naylor's (2012) research in Benin. Farmers also often engage in negotiations and contracting to bring water resources onto their farms from surface or groundwater. These can take varied and complex forms across and even within villages, as illustrated by Michler and Wu (2014) in Bangladesh.

To manage flows of biodiversity harmful to agriculture, there has been significant investment in training on integrated pest and disease management that rely on the application of natural resource-based solutions to reduce threats. This includes providing for a diverse habitat to promote natural predators, to act as barriers (to disease encroachment), or to attract the population of pollinators that are essential for a number of plants (Karp et al. 2018). Managing biodiversity often requires coordination across farms and with mosaics of cultivated and uncultivated lands (including forests and other types of land use). Symbiotic relationships over space and time can also be managed through intercrops or rotations of plants that are complementary in resource use or other ways.

All pastoralists and most agropastoralists depend on pastures for at least some of the fodder for livestock production. In most developing countries, these are not private pastures but shared rangelands, which are often dry or mountainous areas with high spatial and temporal variability (IUCN 2011). Without careful management these lands are subject to degradation through overgrazing or undergrazing, encroachment, or weather and climate changes. 
Paths created by cattle can become significant sources of erosion. Customary systems for rangeland management have often included livestock mobility to access fodder and water resources as well as to prevent undergrazing or overgrazing. Interventions for rangeland improvement may include planting grasses, shrubs, or trees to increase fodder availability, provide shelter, and reduce erosion; limiting grazing (whether by rotating areas to encourage natural regeneration or limiting stocking numbers); and developing or protecting watering points. As with watersheds, improving rangeland conditions depends on effective institutions to accompany any technical interventions (McCarthy 2004).

Forests provide inputs and ecosystem services that are critical for agriculture and rural livelihoods by providing fencing and housing materials, firewood, leaf litter, and other soil amendments to support cultivation, fodder for livestock, and medicinal plants as well as timber and nontimber products to diversify farmers' livelihoods. Beyond their contribution to local livelihoods, the role of forests in carbon sequestration, regulating temperature, rainfall and water flows, and biodiversity mean that not only forest communities or nearby farmers depend on them, but also other stakeholders-from downstream cities (for water regulation) to the global community (for biodiversity and carbon functions). Forests may cover entire landscapes, as in the Amazon, or occur in patches interspersed with cultivated lands and rangelands. Effective management of forests requires regulating cutting and withdrawals as well as selective planting or protecting regrowth. But because of the many different functions and interests in forests, coordinating forest management requires addressing many different stakeholders.

\section{Constraints to Adoption of Natural Resources Management Practices in Agriculture}

A body of research, largely comprised of observational case studies, has found that many NRM practices entail some characteristics or constraints that limit their wide use, such as demands on labor, opportunity costs of land, and uncertainty of long-run returns to investment. While we explore tenure- and governance-related factors here, other factors are featured elsewhere, such as Stevenson and Vlek (2018), covering a range of NRM practices developed by CGIAR; Bationo et al. (2012) on benefits from integrated soil fertility management (ISFM); Yamano, Otsuka, and Place (2011) on various integrative practices in East Africa; Giller et al. (2009) and Corbeels et al. (2014) on adoption challenges for conservation agriculture; and Farrow et al. (2019) on grain legumes in Africa. Furthermore, rural transformation processes 
continue to shift the incentives for undertaking NRM practices. For example, development of input markets and rising rural wages may favor labor-saving technology like herbicides (Haggblade et al. 2017) over labor-intensive land management practices (Jayne et al. 2019).

Constraints to adoption of on-farm NRM practices have been investigated in better designed cause-effect studies in recent years. A study by Michler et al. (2019) on the use of minimum tillage in Zimbabwe found that in normal rainfall years the technology did not pay off and in fact led to economic losses for a number of farmers. Jack et al. (2015) found that dis-adoption of a new technology (planted Faidherbia albida) was common in Zambia due to uncertain information on benefits. Jack and Jayachandran (2018) further investigated the effectiveness of payments for environmental service programs related to tree planting and conservation and found costs of conservation as well as enrollment costs to be important factors in self-selection and participation in the programs. The important conclusion of this body of research is that there are many potential constraints to adoption of natural resource management practices and one or more of them appear to be present in any given developing country contexts. While tenure or governance of resources are among those constraints, the importance of other factors should not be overlooked.

\section{Natural Resources Management Practices and Implications for Property Rights and Collective Action}

Although a full discussion of each of these landscape-level natural resource topics is beyond the scope of this chapter, they share some important features. First, they depend on a careful assessment of the resource conditions, threats, and interrelationships across a large area, to identify points of most effective interventions. Second, effective management usually combines tangible and technical activities, such as building a check dam or planting specific trees, with behavioral or institutional interventions such as rules regarding resource extraction and provision (Anderies and Janssen 2013). Third, there needs to be consideration of the human as well as the biophysical environment: Who are the users and how will they use the resources, and what types of user organizations and government agencies will participate in the development and implementation of the programs?

Figure 18.1 illustrates the need for institutional arrangements to address natural resource management. The lower horizontal scale shows the time scale. Many aspects of soil structure and biological properties require considerable time to rebuild. Agroforestry practices that can improve soils, water flows, and carbon storage also take time for the returns to be realized. The upper 


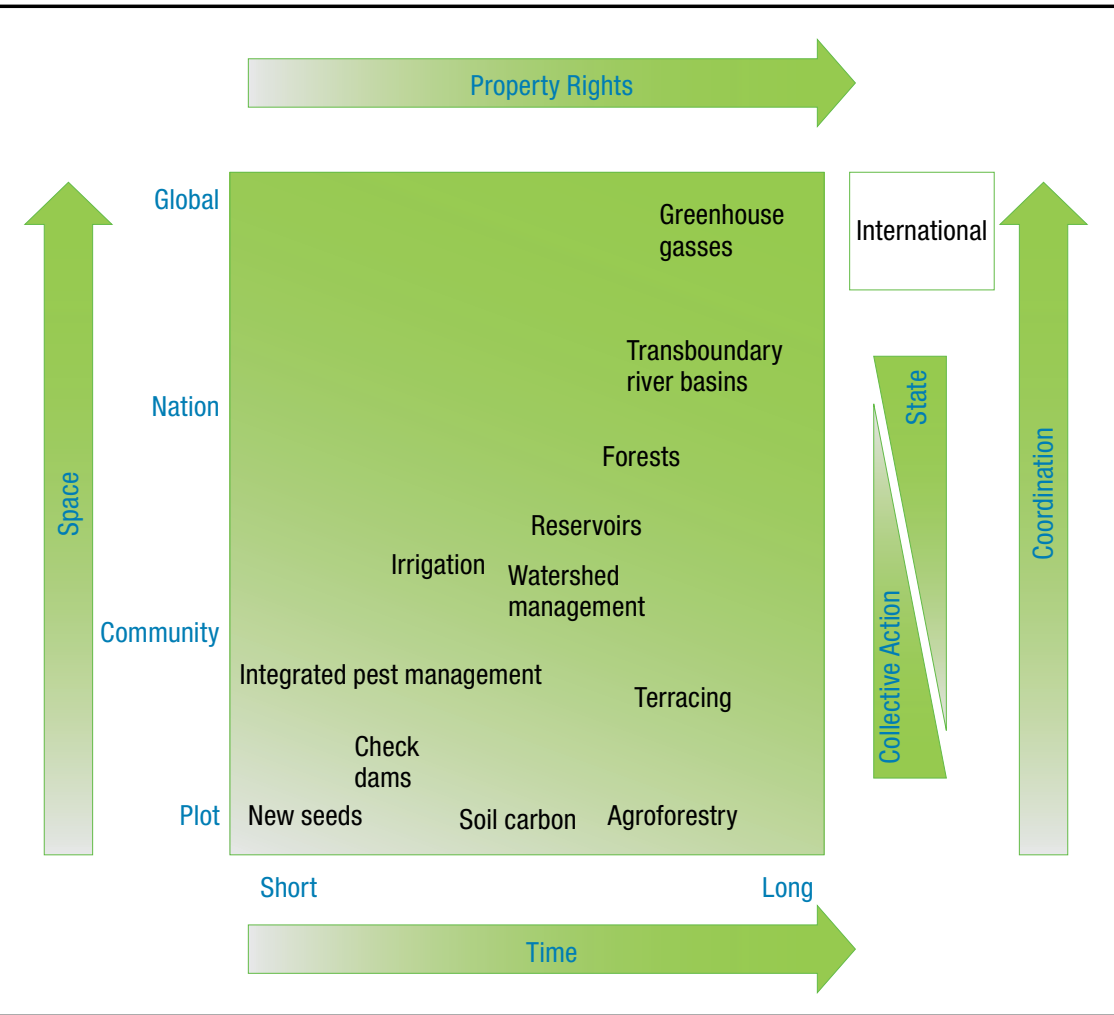

Source: Meinzen-Dick, Markelova, and Moore (2010).

Note: Placement of particular NRM practices is illustrative and depends on the particular characteristics of each practice in each place as well as the size of farms, communities, and nations. NRM = natural resource management.

horizontal scale indicates the corresponding institution (property rights) to deal with long time horizons between investment and returns. Farmers without secure land tenure may have less incentive to invest in long-term soil improvements or may not even be authorized to plant trees. However, in some cases individuals make land investments with the purpose of securing longterm rights to the land, especially by planting trees or careful husbandry of existing land (Bruce and Migot-Adholla 1994; Besley 1995; Otsuka and Place 2001; Platteau 2008).

The vertical axes in Figure 18.1 show the spatial scale and corresponding institutions for coordination. Whereas planting a tree can be done on an individual farm, practices such as integrated pest management (IPM) are more successful when coordination leads to concerted actions by many farmers. 
Most irrigation systems, watershed management, or forests go beyond the boundaries of an individual farm and therefore require some form of coordination of investment (for example, in planting) and extraction. Whether long-term property rights are also important depends on the period of time to positive net benefits. Farmers with weak long-term tenure security may still have incentive for taking short-term measures to reduce pests or apply chemical fertilizer but will not be inclined to invest in structures for soil or water conservation that do not pay off for several years. Ultimately, this framework can be extended to the global scale to address such issues as greenhouse gas emissions or sequestration or widespread loss of biodiversity. Although resource management at the plot, farm, and community level (for example, planting trees or limiting deforestation and hunting) can contribute to addressing these global resource problems, above the level of the nation-state, achieving coordination proves challenging, as discussed in Chapter 19 in this volume.

\section{Tenure and Governance Challenges in Managing Resources}

This section defines concepts and identifies challenges in property rights and coordination of management of natural resources.

\section{Property Rights}

The term "property rights" refers to "claims, entitlements and related obligations among people regarding the use and disposition of a scarce resource" (Furubotn and Pejovich 1972). Although rights to land are the most prominent form of property rights in agriculture and rural areas, rights to water, trees, forests, fisheries, and other aquatic resources are also important, and these may be distinct from the rights to the land on which they are found. According to UN-Habitat (2008), "land tenure" is defined as "the way land is held or owned by individuals and groups, or the set of relationships legally or customarily defined among people with respect to land. In other words, tenure reflects relationships between people and land directly, and between individuals and groups of people in their dealings in land." This definition can be extended to other resources as well.

Most natural resource tenure is characterized by the concurrent existence of multiple legal orders, referred to as "legal pluralism" (Knight 2010; Meinzen-Dick and Pradhan 2002). The most prominent of these are statutory and customary law, but international, religious, and even regulations 
developed by particular programs may also be important. Customary tenure may be or may not be recognized and enforced by the formal legal system. In situations where one system does not recognize the other, the coexistence of customary and statutory tenure could be a source of confusion and may lead to greater tenure insecurity (Knight 2010; USAID 2013). UN-Habitat (2008) presents a range of different tenure types as a continuum from informal to formal rights, with various sets of rights and degrees of security, responsibility, and enforcement. Tenure types and strength and weakness of tenure vary across countries and even across different regions within a country. In particular, different ethnic groups may have different customary laws and rules governing uses of resources. Ultimately, tenure claims are only as strong as the institution that backs them up. This means that in areas where the state is strong, statutory tenure is very important, but where the state is weak (often in more remote areas), customary tenure and resource management rules hold greater sway.

Property rights over natural resources are not limited to "ownership" but are better understood as distinct bundles of rights. There are many ways of classifying the bundles of rights, but Schlager and Ostrom (1992) identify five key bundles that are relevant for resource management.

- Access (for example, to walk across a field)

- Withdrawal (for example, to draw water or harvest plants)

- Management (for example, to plant a crop or tree)

- Exclusion (for example, to prevent others from accessing the field)

- Alienation (for example, to rent out, sell, or give away the rights)

The first two (access and withdrawal) are considered use rights, and the latter three (management, exclusion, and alienation) are control or decisionmaking rights. Galik and Jagger (2015) argue for a sixth bundle-alterationto reflect the right to transform the resource, often by making improvements. "Ownership" often implies having all of these rights, but different bundles of rights are often held by different individuals, groups, or institutions (for example, government agencies) over the same resource. For instance, a farmer may have the right to plant a crop on a piece of land, but anyone can cross that land to get water; pastoralists may have the right to graze their herds on that land in the fallow season; family elders may have the right to allocate or reallocate that land; and the state may claim ultimate "ownership" of the resource. How these bundles of rights are distributed will affect who has authority and 
incentive to manage the resources as well as the distribution of benefits in society.

The holders of these rights can be individuals, households, companies, groups, or the state. The first three are generally referred to as private property; rights held by various forms of groups or collectives are common property, and rights held by the state are public property. Although most farms (especially smallholder farms) are private property, forests, rangelands, and water resources are often common or public property. Even farmers with private holdings may rely on common property for critical inputs to their livelihoods (for example, fuel, animal fodder) and ecosystem services.

The NRM practices discussed earlier can generally be mapped into three different types of management domains: (1) private property management without much externality (for example, improved soil nutrient management); (2) private property management with significant externality (for instance, pest management, soil conservation); and (3) common property management (for example, forest and rangelands). In common property management, communal rights to the resources and coordination mechanisms are important for successful resource management. An example of common property management is the case of forests (see Figure 18.1), where the establishment of governance mechanisms including the establishment of access and ownership rights among various stakeholders is important. The case of private property management with externalities lies between the two other cases. Private property requires clarity and secure rights for the holder, while the presence of externalities clearly indicates the need for coordination.

Place, Roth, and Hazell (1994) identify three dimensions of tenure security: robustness, duration, and assurance of rights. "Robustness" refers to how many of the rights are held. "Duration" is the length of time for which a right is valid. "Assurance" is the certainty with which the rights are held and the extent to which the rights are enforceable. The individual's subjective perception of their own tenure situation is identified as an important factor that influences their behavior (Van Gelder 2010). Investment in land as well as sustainable management of natural resources is based on the perception households and individuals have regarding tenure security in the future, when the return of a current investment in natural resource management is realized in the future.

Increased land tenure security can lead to three other reinforcing channels for increasing investment in land. First, greater tenure security can increase demand for land-related investment by reducing land disputes and freeing up resources for investment that have been spent to defend land 
rights. Second, many formalized tenure systems facilitate land transfers and enable investors to benefit from their investment even if they will not be able to use the land. Third, tenure security can enhance access to credit for investment and inputs (Piza and Moura 2011) and more so where agricultural credit markets are functional (Deininger 2003). In addition to economic benefits, secured land tenure promotes social stability by reducing land conflicts and social exclusion and improving shelter conditions (UN-Habitat 2008; Deininger 2003).

Land tenure (in)security can be measured at farm plot, individual, household, group, or community levels. At the community or group level, tenure security is often measured by indicators such as whether collective land rights are recognized by the government, whether community rights can be held in perpetuity, and whether the law requires the consent of communities before the government or outsiders may acquire their land (Wily et al. 2016). Marginalized ethnic groups often experience less tenure security, especially where the state does not recognize their resource rights. This particularly applies to pastoralists, forest-dwelling communities, or other Indigenous peoples. At the household level, a sense of tenure insecurity may come from the perception that someone may challenge their land rights and eventually make them lose their rights to the land. This threat arises either due to (1) hazard of expropriation by the government (Jacoby, Li, and Rozelle 2002), or (2) encroachment or eviction by other individuals.

Underlying drivers of insecurity may result from foreign interest in land or be related to local socioeconomic trends, such as urban expansion, rural population growth, commercialization of agriculture and other factors, conditioned by the degree of protection the government offers against such risks (Ghebru and Girmachew 2017, 2019; Ghebru and Lambrecht 2017). The individual level is also very important because even if a households' rights to tenure are secure, not all individuals may be secure. In particular, women who depend on men for their access to land face additional layers of tenure insecurity-for example, in cases of widowhood or divorce as well as youth who depend on their elders for land, these individuals may lack full decisionmaking rights (see Chapter 15 in this volume; Ghebru and Girmachew 2018). At the plot level, tenure security may vary based on location, tenure status, and time and mode of acquisition. More remote lands are often less secure than those close to the household, and land in other villages may be even less secure. Thus it is common to find that households operating multiple plots of land will have different levels of tenure security on each of them. Where state law is strong, land with formal titles or other certification giving statutory 
recognition may be stronger than undocumented land under customary law. Common property is often less secure than individual property.

The bundles of rights and implicit security of tenure associated with land are affected by the mode of acquisition. There are modes of acquisition for which long-term rights to land are usually conferred including purchase, inheritance, and gift. Land allocated by formal or traditional authorities represents a dominant form of land acquisition in many developing countries where lack of proper documentation of such land implies an adverse effect on natural resource management. Other modes of acquisition such as renting and sharecropping are mainly for short-term rights to land. This distinction has important consequences for NRM because renting and other short-term acquisitions do not afford sufficient time for the tenant to reap benefits from many of the NRM practices noted in Figure 18.1. Moreover, landlords may restrict tenants from undertaking certain visible long-term investments that could lead to contested rights beyond the agreed-upon termination date of the contract. Thus it is not surprising that studies find lower levels of longterm investment on land under short-term tenure arrangements (Place 2009; Deininger and Jin 2006).

Information and knowledge about rights, legal restrictions, and the various types of threats and protection opportunities matter (Deininger et al. 2008; Ghebru and Girmachew 2018). The government may be the source of the risk or the source of protection against the risk, depending on the setting or the formal land rights recognized by government and held by the individual claiming rights in a piece of land. With conflicting claims over land, the increase in the (in)security of one party may imply a reduction in the (in)security of another party or parties. The strength of (in)security can depend on traditional rights (customs and social norms), modes of land acquisition, legal protection (laws and law enforcement), duration of possession, social networks, political connections and power structure, the degree of scarcity (competition) and value of the land, as well as individual and group abilities.

From an empirical perspective, the types of tenure security weaknesses that pose the greatest challenges differ across and within countries. However, a common empirical finding is that women are less likely to own land and have fewer rights to land than men (see Chapter 15 in this volume; Doss et al. 2015; Kieran et al. 2015). Although a far cry from the myth that women own just 1 percent to 2 percent of the land, the differences between men and women can often be large, as in the case of Niger and Nigeria. Women also may face more challenges in protecting their limited rights in family, customary, or formal conflict resolution mechanisms. This has important implications for the 
bargaining power and well-being of women themselves, their households, and the condition of resources. Individuals/households with more secure tenure have been shown to invest more in terracing and bunding for long-term soil conservation, tree planting, and fallowing of land (Ali et al. 2014; Deininger et al. 2008; Holden, Deininger, and Ghebru 2011; Goldstein et al. 2018), and more so in the case of women (Meinzen-Dick et al. 2019; Goldstein et al. 2018).

\section{Coordination for Resource Governance}

As noted, many natural resource management practices involve positive or negative spatial externalities. Thus coordination is important for adoption. While an individual farmer may be able to construct on-farm water storage or tap groundwater in a well, most surface irrigation requires coordination of multiple farmers and other stakeholders to build and convey the water. As many individual farmers take water from wells, coordination among users becomes important to manage the underlying aquifer sustainably. Similarly, finding the optimal place to put check dams or terracing in watersheds and ensuring that they are maintained requires coordination across multiple stakeholders in the watershed. Forest management requires rules for planting, harvesting, and managing the trees and other resources. Mobility of herds has been a key strategy for sustainable management of rangelands, often over a combination of private and collectively held lands, requiring coordination on what animals can be grazed in what areas at what times (McCarthy 2004).

At higher levels, the state has an important role to play in the coordination of NRM (see the right-hand vertical axis in Figure 18.1), but at the most local (community and group) levels, the state has less effective reach and collective action among users is more important. However, these are not mutually exclusive: government agents may operate at the local level, and federations of user groups can extend collective action to the national level, as exemplified the Federation of Community Forest Users (FECOFUN), which links more than 14,000 community forest user groups in Nepal (McLain and Lawry 2015). Thus the rights and responsibilities of each type of institution, and the relationships between state and collective action, are important for NRM outcomes. Although the specific nature of the coordination differs depending on the resource and context, studies of the commons-shared resources such as water, forests, rangelands, and fisheries-have identified several broad patterns. After systematically comparing numerous case studies of common-pool resources (CPRs) characterized by subtractability (in which one person's use of the resource makes less available to others) and the high costs of excluding 
others from using the resource, Ostrom (1990) identified a set of design principles that characterize many long-enduring CPRs. These have been subsequently validated and updated by Cox, Arnold, and Villamayor Tomás (2010), and include the following:

1. Clearly defined boundaries of the resource itself and the group of authorized users.

2. Congruence between appropriation and provision rules and local conditions, so that the rules make sense in the local context and ensure that the benefits obtained are proportional to the amount of inputs required.

3. Collective-choice arrangements that allow most people affected by the rules to participate in setting or modifying the rules.

4. Monitoring of the resource.

5. Graduated sanctions for breaking the rules.

6. Conflict-resolution mechanisms.

7. Minimal recognition of rights to organize.

8. Nested enterprises so that all the governance activities are organized at multiple levels.

Security of tenure on common property depends on external recognition of the group's rights to the land as well as effective internal governance arrangements that will ensure that resources are effectively managed. The external recognition of collective rights is even more rare than for private lands. In a review of 64 countries, RRI (2015) report that half of the countries recognize less than 5 percent of the country's land area as collectively owned or controlled by Indigenous peoples and local communities, even though the total land area used collectively is many times larger. Reforms that have been implemented to secure tenure for individual and collective resources, as well as efforts to strengthen collective management of common pool resources within and across property boundaries, are examined next.

\section{Policy and Institutional Innovations in Tenure Security and Governance}

Over the past few decades, significant changes that affect land tenure systems were witnessed in many parts of the developing world. These include 
demographic growth, urbanization, migration, livelihood diversification, monetization of the economy and commodification of land, greater integration in the global economy, and cultural change (see Chapters 9-13 as well as Chapters 19 and 20 in this volume). Such changes have especially major implications for the "traditional" or "customary" land tenure system (Cotula and Neves 2007; Ghebru and Lambrecht 2017; Linkow 2016).

\section{Individual Land Rights}

Even though there is a consensus on the importance of tenure security, the mechanisms to secure land rights have been debatable, with countries following different approaches. Many countries, particularly in Asia and parts of Africa, undertook redistributive land reforms to compensate for colonial and postindependence land-ownership inequalities and regressive land-use policies (Sikor and Muller 2009). Such "land to the tiller" programs were intended to remove large landlords and inefficiencies in tenancy arrangements and to provide for a strong smallholder agricultural sector. In other countries land titling and registration programs without redistribution were introduced as one means to increase tenure security, facilitate land markets, and improve access to credit using land as collateral (Deininger and Binswanger 1999).

Although formal land registration is taken as a means to reduce disputes, it might be cause for uncertainty in situations where the wealthy and educated groups use it to capture land from smallholder farmers, women, or communities who have limited or no access to information and are not able to cover the cost of registration. In some situations formal registration fails to recognize the rights of secondary right holders such as women, migrants, and herders (Platteau 2000 cited in Quan and Toulmin 2004; Meinzen-Dick and Mwangi 2007). Moreover, experience of countries has shown that land titling programs were time-consuming, expensive, and not accessible for poor farmers. For instance, only about 1 percent of land in Africa was registered under formal systems in the early 2000s (Easterly 2008).

In recognition of the limitation of land titling programs, alternative approaches have been developed to improve tenure security. Among individual titling and registration programs, some (such as Ethiopia or Rwanda) have made explicit provision for inclusion of women's names as joint owners of household lands. Another approach has been to give legal recognition to customary tenure systems that could be done through direct contact with individual holders of customary rights or nationwide recognition of customary land rights (Van den Brink et al. 2006 cited in Lawry et al. 2017; Palmer et al. 2009). This approach is practiced in some African countries, such as Burkina 
Faso, Ghana, Mali, Mozambique, Niger, and Uganda, that have legally recognized customary tenure (Palmer et al. 2009). In Ghana, Customary Land Secretariats were formed to manage land in peri-urban areas and make arrangements for community members who lost agricultural land because of urban expansion (UN-Habitat 2008). In Uganda the 1998 Land Act recognizes land acquired by households through allocation by customary authorities. In Mozambique the Land Law gave recognition to customary tenure by protecting land rights of communities through a community land delimitation program (Palmer et al. 2009; USAID 2009).

Another approach involves providing intermediate forms of tenure, such as a land certificate, right of occupancy, formalization of leasing or rental transactions, and so on. This type of recognition of land rights is implemented in countries like Brazil, Colombia, Ethiopia, Mexico, Tanzania, and Trinidad and Tobago (Palmer et al. 2009). For instance, in Ethiopia low-cost land certification (for example, not based on formal demarcation) was implemented that provides land-use rights in rural areas (Palmer et al. 2009). Several studies have analyzed the effect of the certification program on Ethiopian households and found benefits in the form of perceived tenure security, investment in land improvements, and in promoting land rentals (Bezabih, Holden, and Mannberg 2016; Deininger et al. 2008; Ghebru and Holden 2013; Holden, Deininger, and Ghebru 2011). In Trinidad and Tobago, Certificates of Comfort are issued to people living in informal settlements, which enable households to use and invest in the land (UN-Habitat 2008). Two recent studies using experimental approaches provided certificates of land rights following boundary demarcation and examined investment behavior in a short period that followed. Goldstein et al. (2018) found significant enhancement of perceived security and land investment in Benin, while Huntington, Haflett, and Ewing (2018) found that the certificates do not affect planting of trees in Zambia.

Despite the various efforts made to improve land governance in many developing countries, tenure insecurity in the form of land disputes among families/neighbors, land expropriation by the government, land grabbing by the elite and foreign investors, and expansion of the informal land market is still a threat to the rural poor and urban dwellers. Empirical studies have found mixed results in the impact of land titling and registration on investment, access to credit, land rights of vulnerable groups (female, migrants, economically poor), and agricultural productivity. In a systematic review of the impact of tenure reforms in developing countries, Lawry et al. (2017) found no evidence for a credit mechanism. In another systematic review, Higgins et 
al. (2018) report that only two of seven studies found a link between improved tenure security and credit. However, both of these systematic reviews found stronger evidence of land tenure recognition programs on investment in the land, particularly in long-term improvements in the natural resources.

In their systematic review of women's land rights on poverty reduction, Meinzen-Dick et al. (2019) found a similar pattern: greater tenure security for women led to increased investments in tree planting as well as terracing and bunding to reduce soil erosion. However, not all titling or registration programs strengthen women's land rights; without special efforts to ensure that women's names are recorded as sole land owners or jointly with their spouses, the effect of the registration may be to reduce the rights women have under customary tenure (Lastarria-Corhiel 1997). Lawry et al. (2017) also found substantial productivity and income gains from land tenure recognition, but these were greater in Asia and Latin America than in Africa. Underestimating the contribution of customary tenure systems to farmers' tenure security, lower level of household income to make investment in agriculture, and lack of complementary public investments (in infrastructure, provision of input and market access, training for farmers) to support agricultural investment are mentioned as possible causes for the weaker linkage in Africa.

Beyond land registration, recognition of land rights by the community, availability of an institution to enforce land rights, duration of land rights, clear definition of land rights and boundary demarcation of land are important contributors to security of land tenure (Abdulai and Antwi 2005). Moreover, the insecurity of "informal" or customary rights is overestimated. Williamson and Kerekes (2011) found that the role of informal institutions has been underestimated, and the efforts to secure property rights through formal means cannot be effective without considering informal practices in the society.

\section{Communal Rights}

Formalization of individual rights is not the only form of tenure reforms that is important for natural resource management. Many countries have or are engaging in reforms to strengthen collective land and resource rights, notably for forests and rangelands. More than 73 percent of forests remain formally under state ownership (RRI 2014), with government forestry agencies relying on regulation and policing of forest use, often with adversarial relations with communities (Lawry et al. 2012). In recent years there have been notable initiatives to devolve rights to forests, in particular, from the state to communities. Progress has been most noted in Latin America (especially Bolivia, Brazil, 
Colombia, Honduras, and Peru), with both long-term community or group concessions and titling of Indigenous peoples' domains (Lawry et al. 2012). In Asia the state has devolved a more limited set of forest resource rights to communities, notably in China, India, Indonesia, Nepal, and the Philippines.

However, these co-management arrangements between the state and communities often limit use of high-value forest resources (especially timber). Often it is only degraded forest lands that are transferred to communities or forest user groups, with requirements to use particular practices to restore degraded forest lands. Forest tenure reform is most limited in Africa, with restrictions even on rights to trees on private land. Lawry et al. (2012) note numerous successes of cases that strengthen community rights to forests and trees, but "tenuous use rights and weak benefit-sharing models only go so far toward providing the security and financial incentives needed to invest in forest improvements and protection at landscape-scales" (Lawry et al. 2012: viii).

For example, with unclear benefit-sharing arrangements, restoration through planting and management of high-value species will be inhibited, although enclosure methods may still take place (Otsuka and Place 2001). Furthermore, even when countries adopt policies to devolve rights, these are often not implemented because of opposition from elites or forest agencies; even if they are implemented, communities may require more than secure tenure: strengthening cooperatives, training, and other resources may be required to sustainably exploit forest resources (Larson et al. 2016). However, reviewing cases from Guatemala, Mexico, Namibia, and Nepal, Gnych et al. (2018) found that devolution of forest rights that gives communities secure tenure has catalyzed investment in collectively held forests and other natural resources, with environmental and social returns as well as profits. But this also requires the emergence of legitimate community-level governance organizations for benefit sharing within the communities and capacity to engage with external state and market actors.

As noted, pastoralists rely on mobility across large areas to sustainably exploit rangelands and have historic claims to use rights over large areas as well as complex arrangements to access areas in extreme years, which are not easily accommodated in formal tenure systems. Indeed, the formalization process and recognition of individual tenure has often been a threat to pastoralists' tenure: "As a landscape is progressively surveyed, demarcated and allocated, pastoralists' mobility may be obstructed and their practices of repeatedly renegotiating access rights to resources become less effective, essentially depriving them of those rights" (Davies et al. 2016: 20). Securing tenure for pastoralists therefore requires a different way of thinking about the land: 
instead of exclusive, individual holdings, accommodating overlapping collective rights, recognizing customary institutions, and building capacity of pastoralists, other communities, and government to negotiate and resolve conflicts (Davies et al. 2016). For example, Tanzania's Village Land Use Planning process was often missing pastoralists because they moved across village boundaries. A new Joint Village Land Use Planning process across village boundaries where pastoralists move allowed for better representation of pastoralists and led to issuing of group certificates of customary rights of occupancy (CCROs) (ILC 2014).

Participatory land-use planning approaches that bring together various stakeholders-including diverse local resource users, local government, and line agencies - to organize resource uses and practices are also used in watershed management. UN-Habitat (2016) identifies ways that tenure-sensitive land-use planning can help strengthen the resource rights of local resource users, especially those with more insecure tenure. Although the participation of stakeholders in such planning processes is likely to increase compliance with plans for resource use, plans alone are not sufficient. Some form of institutions are needed for ongoing activities such as setting and enforcing operational rules and managing conflicts. Many watershed, irrigation, or forest programs have responded to this by setting up formalized user groups, but effective coordination is more likely if programs identify and build on existing bases of cooperation, either through customary (for example, tribal) institutions or forms of forest or water users' groups.

Because of the wide variability of social and ecological systems over space and time, there is no single formula that works for all conditions. Rather, many countries and programs seek to establish adaptive collaborative management (or "adaptive co-management") arrangements that involve sharing of rights and responsibilities by government and civil society, combined with an adaptive learning process that draws on both local and external scientific knowledge to deal with complex systems (Armitage, Berkes, and Doubleday 2007). Instead of blueprint approaches to establish steady state conditions, these call for flexibility to create resilience of linked human and natural resource systems.

\section{Conclusion}

With population continuing to grow while additional land available for agriculture is shrinking, there is no doubt that maintaining or improving the status of natural resources already in use for agricultural resources is critical for 
future food security. There are numerous management practices that can safeguard or enrich the natural resource base, but their application in developing countries needs to be greatly expanded. Constraints to wider use are manifested at various levels. Price incentives may be weak, especially in remote areas, and dampen enthusiasm for undertaking any type of investment in agriculture. Uptake of nontraditional NRM practices may face basic informational constraints (for example, for conservation agriculture). Market constraints may limit availability of seed of leguminous plants or equipment for some land or water management improvements. Some farm-level practices are land consuming (for instance, rotations, fallows) while others are labor intensive (for example, composting, terracing) and may therefore be attractive only to households with available resources. Landscape-level practices are inhibited by lack of functional mechanisms for coordination. Finally, weak tenure security has a significant impact on the willingness of farmers and communities to invest in NRM.

There are many mechanisms at the disposal of governments to improve incentives, but a key one will be the improvement of tenure security over resources. Recent institutional innovations have proven that tenure security enhancement can be made efficiently and equitably without expensive demarcation of rights at the household or plot level. It is not a given, however, that legislation or regulation will enhance tenure security for the groups who are in most need. There is need for investment in awareness creation and capacity development to operationalize reforms. A challenge facing policymakers is that there is no single tenure policy or institutional blueprint that will prove to be the best option in all countries or even all locations within a country. From an agricultural perspective, the natural resource and tenure priorities will continue to differ for rainfed versus irrigated areas, for sedentary versus pastoral areas, for key cash/export crop areas versus staple food areas, and for peri-urban versus remote areas. In addition, sound stewardship of natural resources requires attention to their management at different spatial scales, from the plot to global scale, and the voice of future generations needs to be heard. This poses a tremendous coordination challenge for which mechanisms are still elusive. Finally, demographic, economic, and other forces will undoubtedly require modifications to today's tenure and coordination institutions.

Learning what works under which national and local contexts will continue to be a priority of researchers in support of property rights reforms and sustainable governance of resources. Multiple methods contribute to this learning. Detailed case studies provide nuanced insights. Systematic 
comparisons of multiple case studies (for example, Ostrom 1990; Cox, Arnold, and Villamayor Tomás 2010) and qualitative comparative analysis (QCA) help to identify the conditions that shape outcomes. Although it is generally difficult to randomize natural resource conditions, there have been some randomized controlled trials and other quasi-experimental methods to assess the impact of interventions, especially in tenure security (for example, Deininger et al. 2008), and systematic reviews (for example, Lawry et al. 2017; Higgins et al. 2018) build the evidence base across multiple interventions in different contexts. Given the multiple factors affecting natural resource management, no single approach can provide definitive answers. Rather, it is important to triangulate among different methods, perspectives, resources, and regions to improve our understanding of what contributes to (or undermines) sustainable natural resource management.

\section{References}

Abdulai, R., and A. Antwi. 2005. "Traditional Landholding Institutions and Individual Ownership of Land Rights in Sub-Saharan Africa." World Review of Science, Technology and Sustainable Development 2: 302-319.

AGRA (Alliance for a Green Revolution in Africa). 2013. African Agriculture Status Report 2013. Nairobi.

Ali, D., K. Deininger, and M. Goldstein. 2014. "Environmental and Gender Impacts of Land Tenure Regularization in Africa: Pilot Evidence from Rwanda." Journal of Development Economics 110: 262-275.

Anderies, J. M., and M. A. Janssen. 2013. Sustaining the Commons. Tempe: Arizona State University.

Armitage, D., F. Berkes, and N. Doubleday. 2007. Adaptive Co-Management: Collaboration, Learning and Multi-Level Governance. Vancouver, Canada: UBC Press.

Bationo, A., B. Waswa, J. Kihara, I. Adolwa, B. Vanlauwe, and K. Saidou, eds. 2012. Lessons Learned from Long-Term Soil Fertility Management Experiments in Africa. Dordrecht, Netherlands: Springer Press.

Besley, T. 1995. "Property Rights and Investment Incentives: Theory and Evidence from Ghana." Journal of Political Economy 103 (5): 903-937.

Bezabih, M., S. Holden, and A. Mannberg. 2016. "The Role of Land Certification in Reducing Gaps in Productivity between Male- and Female-Owned Farms in Rural Ethiopia." Journal of Development Studies 52 (3): 360-376. 
Bruce, J. W., and S. E. Migot-Adholla, eds. 1994. Searching for Land Tenure Security in Africa. Dubuque, IA: Kendall/Hunt Publishing Co.

Burney, J., and R. Naylor. 2012. "Smallholder Irrigation as a Poverty Alleviation Tool in SubSaharan Africa." World Development 40 (1): 110-123.

Calzadilla, A., T. Zhu, K. Rehdanz, R. S. J. Tol, and C. Ringler. 2013. "Economywide Impacts of Climate Change on Agriculture in Sub-Saharan Africa." Ecological Economics 93 (September): 150-165.

Comprehensive Assessment of Water Management in Agriculture. 2007. Water for Food, Water for Life: A Comprehensive Assessment of Water Management in Agriculture. London: Earthscan; Colombo, Sri Lanka: International Water Management Institute.

Corbeels, M., J. de Graaff, T. H. Ndah, E. Penot, F. Baudron, K. Naudin, and L. Rusinamhodzi. 2014. "Understanding the Impact and Adoption of Conservation Agriculture in Africa: A Multi-Scale Analysis." Agriculture Ecosystem and Environment 187: 155-170.

Cotula, L., and B. Neves. 2007. "The Drivers of Change." In Changes in "Customary" Land Tenure Systems in Africa, edited by L. Cotula, 15-31. London: International Institute for Environment and Development.

Cox, M., G. Arnold, and S. Villamayor Tomás. 2010. "A Review of Design Principles for Community-Based Natural Resource Management." Ecology and Society 15 (4): 38.

Davies, J., P. Herrera, J. Ruiz-Mirazo, J. Mohamed-Katerere, I. Hannam, and E. Nuesri. 2016. Improving Governance of Pastoral Lands Implementing the Voluntary Guidelines on the Responsible Governance of Tenure of Land, Fisheries and Forests in the Context of National Food Security. Governance of Tenure Technical Guide 6. Rome: FAO.

Deininger, K. 2003. Land Policies for Growth and Poverty Reduction. Washington, DC: World Bank.

Deininger, K., D. A. Ali, S. Holden, and J. Zevenbergen. 2008. "Rural Land Certification in Ethiopia: Process, Initial Impact, and Implications for Other African Countries." World Development 36 (10): 1786-1812.

Deininger, K., and H. Binswanger. 1999. “The Evolution of the World Bank's Land Policy: Principles, Experience, and Future Challenges.” World Bank Research Observer 14 (2): 247-276.

Deininger, K., and S. Jin. 2006. “Tenure Security and Land Related Investment: Evidence from Ethiopia." European Economic Review 50 (5): 1245-1277.

Doss, C., C. Kovarik, A. Peterman, A. Quisumbing, and M. van den Bold. 2015. “Gender Inequities in Ownership and Control of Land in Africa: Myth and Reality." Agricultural Economics 46 (3): 403-434. 
Easterly, W. 2008. "Design and Reform of Institutions in LDCs and Transition Economics: Institutions Top Down or Bottom Up?” American Economic Review 98 (2): 95-99.

Ellison, D., C. Morris, B. Locatelli et al. 2017. “Trees, Forests and Water: Cool Insights for a Hot World." Global Environmental Change 43: 51-61.

FAO (Food and Agriculture Organization of the United Nations). 2011. The State of the World's Land and Water Resources for Food and Agriculture (SOLAW)_Managing Systems at Risk. Rome: FAO; London: Earthscan.

. 2012a. State of the World's Forests. Rome.

- 2012b. World Agriculture towards 2030/2050: The 2012 Revision, by N. Alexandratos and J. Bruinsma. ESA Working Paper 12-03, June. Rome.

Farrow, A., E. Ronner, G. van den Brand et al. 2019. "From Best Fit Technologies to Best Fit Scaling: Incorporating and Evaluating Factors Affecting the Adoption of Grain Legumes in Sub-Saharan Africa." Experimental Agriculture 55: 226-251.

Food and Land Use Coalition. 2019. Growing Better: Ten Critical Transitions to Transform Food and Land Use. Global Consultation Report of the Food and Land Use Coalition.

Furubotn, E. G., and S. Pejovich. 1972. "Property Rights and Economic Theory: A Survey of Recent Literature.” Journal of Economic Literature 10 (4): 1137-1162.

Galik, C. S., and P. Jagger. 2015. "Bundles, Duties, and Rights: A Revised Framework for Analysis of Natural Resource Property Rights Regimes." Land Economics 91 (1): 76-90.

Ghebru, H., and F. Girmachew. 2017. Scrutinizing the Status Quo: Rural Transformation and Land Tenure Security in Nigeria. IFPRI-NSSP Working Paper 43. Washington, DC: IFPRI.

- 2019. Perceived Tenure (In)security in the Era of Rural Transformation: GenderDisaggregated Analysis from Mozambique. IFPRI Discussion Paper 1799. Washington, DC: IFPRI.

Ghebru, H., and S. Holden. 2013. Links between Tenure Security and Food Security: Evidence from Ethiopia. IFPRI Discussion Paper 1288. Washington, DC: IFPRI.

Ghebru, H., and I. Lambrecht. 2017. "Drivers of Perceived Land Tenure (In)Security: Empirical Evidence from Ghana." Land Use Policy 66: 293-303.

Giller, K., E. Witter, M. Corbeels, and P. Tittonell. 2009. "Conservation Agriculture and Smallholder Farming in Africa: The Heretics' View.” Field Crops Research 114: 23-34.

Gnych, S., S. Lawry, I. Monterroso, and A. Adhikary. 2018. "Common Benefits: Is Community Tenure Facilitating Investment in the Commons for Inclusive and Sustainable Development?" Paper presented at the "2018 World Bank Conference on Land and Poverty," Washington, DC, March 19-23. 
Goldstein, M., K. Hounkebedji, F. Kondylis, M. O’Sullivan, and H. Selod. 2018. “Formalization without Certification? Experimental Evidence on Property Rights and Investment." Journal of Development Economics 132: 57-74.

Gollin, D., D. Lagakos, and M. Waugh. 2014. “The Agricultural Productivity Gap.” Quarterly Journal of Economics 129 (2): 939-993.

Haggblade, S., B. Minten, C. Pray, T. Reardon, and D. Zilberman. 2017. “The Herbicide Revolution in Developing Countries: Patterns, Causes, and Implications." European Journal of Development Research 29 (3): 533-559.

Henao, J., and C. Banaante. 2006. Agricultural Production and Soil Nutrient Mining in Africa: Implications for Resource Conservation and Policy Development: Summary. Muscle Shoals, AL: International Fertilizer Development Center.

Higgins, D., T. Balint, H. Liversage, and P. Winters. 2018. "Investigating the Impacts of Increased Rural Land Tenure Security: A Systematic Review of the Evidence." Journal of Rural Studies 61: $34-62$.

Holden, S., K. Deininger, and H. Ghebru. 2011. “Tenure Insecurity, Gender, Low-Cost Land Certification, and Land Rental Market Participation in Ethiopia." Journal of Development Studies 47 (1): 31-47.

Huntington, H., A. Haflett, and B. Ewing. 2018. "The Impact of Interventions to Promote Climate Change Adaptation: Does Stronger Tenure Security Increase Farmer Investment in Sustainable Agroforestry?” Paper presented at the "2018 World Bank Conference on Land and Poverty," Washington, DC, March 19-23.

ILC (International Land Coalition). 2014. Participatory Rangeland Resource Mapping in Tanzania. Rome.

IUCN. 2011. Supporting Sustainable Pastoral Livelihoods: A Global Perspective on Minimum Standards and Good Practices. Nairobi.

Jack, B., P. Oliva, C. Severen, E. Walker, and S. Bell. 2015. “Technology Adoption under Uncertainty: Take-Up and Subsequent Investment in Zambia." NBER Working Paper 21414. National Bureau of Economic Research, Cambridge, MA.

Jack, K., and S. Jayachandran. 2018. "Self-Selection into Payments for Ecosystem Services Programs." Proceedings of the National Academy of Sciences 116 (12): 5326-5333.

Jacoby, H., G. Li, and S. Rozelle. 2002. "Hazards of Expropriation: Tenure Insecurity and Investment in Rural China." American Economic Review 92 (5): 1420-1447.

Jayne, T., S. Snapp, F. Place, and N. Sitko. 2019. "Sustainable Agricultural Intensification in an Era of Rural Transformation in Africa." Global Food Security 20: 105-113. 
Karp, D. S., R. Chaplin-Kramer, T. D. Meehan et al. 2018. "Crop Pests and Predators Exhibit Inconsistent Responses to Surrounding Landscape Composition." Proceedings of the National Academy of Sciences (PNAS) 115 (33): E7863-E7870.

Kerr, J. 2007. “Watershed Management: Lessons from Common Property Theory." International Journal of the Commons 1 (1): 89-110.

Kieran, C., K. Sproule, C. Doss, A. Quisumbing, and S. M. Kim. 2015. "Examining Gender Inequalities in Land Rights Indicators in Asia.” Agricultural Economics 46: 119-138.

Kissinger, G., M. Herold, and V. De Sy. 2012. "Drivers of Deforestation and Forest Degradation: A Synthesis Report for REDD+ Policymakers.” Lexeme Consulting, Vancouver.

Knight, S. R. 2010. Statutory Recognition of Customary Land Rights in Africa. Rome: FAO.

Kremin, C., and A. Miles. 2012. "Ecosystem Services in Biologically Diversified versus Conventional Farming Systems Benefits, Externalities, and Trade-Offs." Ecology and Society $17(4): 40$.

Kroeger, T., and F. Casey. 2007. "An Assessment of Market-Based Approaches to Providing Ecosystem Services on Agricultural Lands." Ecological Economics 64 (2): 321-332.

Larson, A. M., I. Monterroso, M. R. Banjade, and E. Mwangi. 2016. "Community Rights to Forests in the Tropics: Progress and Retreat on Tenure Reforms." In Comparative Property Law: Global Perspectives, edited by M. Graziadei and L. Smith, 435-457. Cheltenham, UK: Edward Elgar.

Lasco, R., R. J. Delfino, D. Catacutan, E. Simelton, and D. Wilson. 2014. “Climate Risk Adaptation by Smallholder Farmers: The Roles of Trees and Agroforestry." Current Opinion in Environmental Sustainability 6: 83-88.

Lastarria-Cornhiel, S. 1997. "Impact of Privatization on Gender and Property Rights in Africa." World Development 25 (8): 1317-1333.

Lawry, S., R. McLain, B. Swallow, K. Biedenweg, and M. Matt Sommerville. 2012. Devolution of Forest Rights and Sustainable Management Volume 1: A Review of Policies and Programs in 16 Developing Countries. Washington, DC: Tetra Tech ARD.

Lawry, S., C. Samii, R. Hall, A. Leopold, D. Hornby, and F. Mtero. 2017. “The Impact of Land Property Rights Interventions on Investment and Agricultural Productivity in Developing Countries: A Systematic Review." Journal of Development Effectiveness 9 (1): 61-81.

Le, Q. B., E. Nkonya, and A. Mirzabaev. 2016. "Biomass Productivity-Based Mapping of Global Land Degradation Hotspots." In Economics of Land Degradation and Improvement: A Global Assessment for Sustainable Development, edited by E. Nkonya, A. Mirzabaev, and J. von Braun, 55-84. Cham, Switzerland: Springer Open. 
Linkow, B. 2016. "Causes and Consequences of Perceived Land Tenure Insecurity: Survey Evidence from Burkina Faso." Land Economics 92 (2): 308-327.

Marenya, P., and C. Barrett. 2009. "Soil Quality and Fertilizer Use Rates among Smallholder Farmers in Western Kenya." Agricultural Economics 40 (5): 561-572.

McCarthy, N. 2004. Managing Resources in Erratic Environments: An Analysis of Pastoralist Systems in Ethiopia, Niger, and Burkina Faso. Research Report 135. Washington, DC: International Food Policy Research Institute (IFPRI).

McLain, R. J., and S. Lawry. 2015. "Good Governance: A Key Element of Sustainable Nontimber Forest Product Harvesting Systems.” In Ecological Sustainability and Non-Timber Forest Products, edited by C. M. Shackleton, A. K. Pandey, and T. Ticktin, 235-259. London: Routledge.

Meinzen-Dick, R., H. Markelova, and K. Moore. 2010. The Role of Collective Action and Property Rights in Climate Change Strategies. CAPRi Policy Brief 7. Washington, DC: IFPRI.

Meinzen-Dick, R., and E. Mwangi. 2007. "Cutting the Web of Interests: Pitfalls of Formalizing Property Rights." Land Use Policy 26: 36-43.

Meinzen-Dick, R. S., and R. Pradhan. 2002. Legal Pluralism and Dynamic Property Rights. CAPRi Working Paper 22. Washington, DC: IFPRI.

Meinzen-Dick, R. S., A. R. Quisumbing, C. R. Doss, and S. Theis. 2019. "Women's Land Rights As a Pathway to Poverty Reduction: Framework and Review of Available Evidence." Agricultural Systems 172: $72-82$.

Michler, J., K. Baylis, M. Arends-Kuenning, and K. Mazvimavi. 2019. “Conservation Agriculture and Climate Resilience." Journal of Environmental Economics and Management 93: 148-169.

Michler, J., and S. Wu. 2014. "The Effects of Governance on Relational and Formal Contracts: Theory and Evidence from Groundwater Irrigation Markets." Paper presented at 4th International Rice Conference, Bangkok.

Ostrom, E. 1990. Governing the Commons: The Evolution of Institutions for Collective Action. Cambridge: Cambridge University Press.

Otsuka, K., and F. Place. 2001. Land Tenure and Natural Resource Management: A Comparative Study of Agrarian Communities in Asia and Africa. Baltimore: Johns Hopkins University Press for IFPRI.

Palmer, D., S. Fricska, B. Wehrmann et al. 2009. Towards Improved Land Governance. Land Tenure Working Paper 11. Rome: FAO and United Nations Human Settlements Program.

Peoples, M., J. Brockwell, D. Herridge et al. 2009. "The Contributions of Nitrogen-Fixing Crop Legumes to the Productivity of Agricultural Systems." Symbiosis 48 (1): 1-17. 
Piza, C., and M. Moura. 2011. "How Does Land Title Affect Access to Credit? Empirical Evidence from an Emerging Economy." Working Paper Series 2211, University of Sussex Business School, Brighton.

Place, F. 2009. "Land Tenure and Agricultural Productivity in Africa: A Comparative Analysis of the Economics Literature and Recent Policy Strategies and Reforms." World Development 37: 1326-1336.

Place, F., M. Roth, and P. Hazell. 1994. "Land Tenure Security and Agricultural Performance in Africa: Overview of Research Methodology." In Searching for Land Tenure Security in Africa, edited by J. W. Bruce and S. Migot-Adholla, 15-40. Washington, DC: World Bank.

Platteau, J.-P. 2008. “The Evolutionary Theory of Land Rights as Applied to Sub-Saharan Africa: A Critical Assessment." Development and Change 27 (1): 29-86.

Quan, J., and C. Toulmin. 2004. “Formalizing and Securing Land Rights in Africa." In Land in Africa: Market Asset or Secure Livelihood, Proceedings and Summary of Conclusions from the Land in Africa Conference, edited by J. Quan, S. Fei Tan, and C. Toulmin, 133-162. London: IIED.

Rockström, J., W. Steffen, K. Noone et al. 2009. “Planetary Boundaries: Exploring the Safe Operating Space for Humanity.” Ecology and Society 14 (2): 32.

RRI (Rights and Resources Initiative). 2014. What Future for Reform? Progress and Slowdown in Forest Tenure Reform since 2002. Washington, DC.

- 2015. Who Owns the World's Land? A Global Baseline of Formally Recognized Indigenous and Community Land Rights. Washington, DC.

Salzman, J., G. Bennett, N. Carroll, A. Goldstein, and M. Jenkins. 2018. "The Global Status and Trends of Payments for Ecosystem Services." Nature Sustainability 1: 136-144.

Sanchez, P. 2019. Properties and Management of Soils in the Tropics. Cambridge: Cambridge University Press.

Schlager, E., and E. Ostrom. 1992. "Property-Rights Regimes and Natural Resources: A Conceptual Analysis." Land Economics 68 (3): 249-262.

Sikor, T., and D. Muller. 2009. "The Limits of State-Led Land Reform: An Introduction." World Development 37 (8): 1307-1316.

Stevenson, J. R., and P. Vlek. 2018. Assessing the Adoption and Diffusion of Natural Resource Management Practices: Synthesis of a New Set of Empirical Studies. Rome: Independent Science and Partnership Council (ISPC).

Tamene, L., and Q. B. Le. 2015. "Estimating Soil Erosion in Sub-Saharan Africa Based on Landscape Similarity Mapping and Using the Revised Universal Soil Loss Equation (RUSLE)." Nutrient Cycling in Agroecosystems 102: 17-31. 
2030 Water Resources Group. 2009. Charting Our Water Future: Economic Frameworks to Inform Decision-Making. McKinsey.

UN-Habitat. 2008. Secure Land Rights for All. Nairobi: United Nations Human Settlements Programme.

_.2016. Tenure Responsive Land Use Planning: A Guide for Country Level Implementation. Nairobi.

USAID (US Agency for International Development). 2009. Integrating Customary Land Tenure into Statutory Land Law: A Review of Experience from Seven Sub-Saharan African Countries and the Kyrgyz Republic. Property Rights and Resource Governance Project.

— 2013. The Future of Customary Tenure: Options for Policymakers. USAID Issue Brief.

Van Gelder, L. J. 2010. “What Tenure Security? The Case of a Tripartite View.” Land Use Policy 27: 449-456.

Vanlauwe, B., K. Descheemaeker, K. Giller et al. 2015. "Integrated Soil Fertility Management in Sub-Saharan Africa: Unravelling Local Adaptation.” Soil 1: 491-508.

Weisse, M., and E. D. Goldman. 2018. "2017 Was the Second-Worst Year on Record for Tropical Tree Cover Loss.” Blog, World Resources Institute, June 26.

Williamson, R. C., and C. B. Kerekes. 2011. "Securing Private Property: Formal versus Informal Institutions." Journal of Law and Economics 54: 537-572.

Wily, L. A., N. Tagliarino, A. Vidal, C. Salcedo-La Vina, S. Ibrahim, and B. Almeida. 2016.

Indicators of the Legal Security of Indigenous and Community Lands. Data file from LandMark: The Global Platform of Indigenous and Community Lands. www.landmarkmap .org.

Yamano, T., K. Otsuka, and F. Place. 2011. Emerging Development of Agriculture in East Africa: Markets, Soils and Innovations. Dordrecht, Netherlands: Springer Press.

Zomer, R., H. Neufeldt, J. Xu et al. 2016. "Global Tree Cover and Biomass Carbon on Agricultural Land: The Contribution of Agroforestry to Global and National Carbon Budgets." Nature Scientific Reports 6: 29987. 
